\title{
Assessing potential of weeds (Acalypha indica and Amaranthus viridis) in phytoremediating soil contaminated with heavy metals-rich effluent
}

\author{
Dharitri B. Ramanlal ${ }^{1} \cdot$ Rita N. Kumar ${ }^{1} \cdot$ Nirmal Kumar $^{2} \cdot$ Rashmi Thakkar $^{1}$
}

Received: 19 November 2019 / Accepted: 29 April 2020 / Published online: 12 May 2020

(c) Springer Nature Switzerland AG 2020

\begin{abstract}
This study presents the phytoremediation potential of two species Acalypha indica and Amaranthus viridis grown over soil spiked with two doses of paint industry effluent (i.e., $50 \%$ and $100 \%$ ) containing four heavy metals $\mathrm{Pb}, \mathrm{Zn}, \mathrm{Cr}$ and $\mathrm{Cu}$. The species were allowed to grow in the effluent spiked soil for a period of 45 days in which they were harvested and given for heavy metal analysis. The species were checked for the accumulation of $\mathrm{Pb}, \mathrm{Zn}, \mathrm{Cr}$ and $\mathrm{Cu}$ in its root, shoot and the residual in the soil. The accumulation across all the treatments was highly significant $(P<0.05)$ in case of both the species. In $50 \%$ treatment, $A$. indica accumulated $15.33 \mathrm{mg} / \mathrm{kg}$ and $5.14 \mathrm{mg} / \mathrm{kg}$ in the root and shoot, respectively, whereas in $100 \%$ treatment, it accumulated $58.52 \mathrm{mg} / \mathrm{kg}$ and $10.39 \mathrm{mg} / \mathrm{kg} \mathrm{Zn}$ in root and shoot, respectively. Amaranthus viridis accumulated $2.81 \mathrm{mg} / \mathrm{kg}$ and $15.83 \mathrm{mg} / \mathrm{kg} \mathrm{Zn}$ in the root and shoot exposed to $50 \%$ treatment and $27.08 \mathrm{mg} / \mathrm{kg}$ and $41.08 \mathrm{mg} / \mathrm{kg} \mathrm{Zn} \mathrm{in} \mathrm{root} \mathrm{and} \mathrm{shoot} \mathrm{exposed} \mathrm{to} 100 \%$ treatment; it also accumulated $5.54 \mathrm{mg} / \mathrm{kg}$ and $12.0 \mathrm{mg} / \mathrm{kg} \mathrm{Cr}$ in the root and the shoot zones, respectively, pertaining to $50 \%$ treatment and $17.84 \mathrm{mg} / \mathrm{kg}$ and $21.45 \mathrm{mg} / \mathrm{kg}$ in $100 \%$ treatment. Hence, the TF value obtained in the case of $A$. indica was $>1$ only for $\mathrm{Cr}$, while it was $<1 \mathrm{for} \mathrm{Pb}, \mathrm{Zn}$ and $\mathrm{Cu}$, whereas in the case of $A$. viridis, it was $>1$ for $\mathrm{Zn}$ and $\mathrm{Cr}$ and $<1$ for $\mathrm{Pb}$ and $\mathrm{Cu}$.
\end{abstract}

Keywords Heavy metals · Phytoextraction · Translocation factor · Bioconcentration factor

\section{Introduction}

Heavy metals are the most toxic pollutants. They cause irreversible harm and deleterious effects to the environment. Heavy metals are non-biodegradable and thus tend to bioaccumulate in the tissues of humans and several other organisms [23]. It occurs naturally as constituents of the parental rocks and soil as well as the oceanic sediments. Their main entry into the environment is via weathering of the rocks as well as volcanic activities [42]. The other main sources of heavy metal contamination in the environment are anthropogenic activities [64]. The effluents from the industrial units and factories, waste water discharge, sewage discharge, agricultural run-off, etc., are the major anthropogenic sources of soil, surface as well as ground water contamination [5]. Heavy metals once entering the groundwater via soil make the drinking water unfit for consumption as well as irrigation activities [39]. The overall global production of toxic metals has escalated since 1850's [26]. The developing nations have been adversely affected by these toxicants due to overpopulation, resource limitations, improper disposal and lack of awareness. Studies revealed the concentrations of current heavy metal deposits to be almost 10-30 times

Dharitri B. Ramanlal, dharitripateleso@gmail.com; Rita N. Kumar, ritankumar@yahoo.co.in; Nirmal Kumar, nirmalkumar@edu.co.in; Rashmi Thakkar, reshamthakkar@gmail.com | 'Department of Biological and Environmental Science, N. V. Patel College of Pure and Applied Sciences, Vallabh Vidyanagar, Gujarat 388120, India. ${ }^{2}$ P.G. Department of Environmental Science and Technology (EST), Institute of Science and Technology for Advanced Studies and Research (ISTAR), Vallabh Vidyanagar, Gujarat 388120, India. 
higher than the background levels especially noted during 1970s [41]. The recent cases of heavy metal polluted soil have erupted abruptly owing to the improper management of industrial effluents [45]. The concentration of heavy metals in soil is a matter of concern as it can have multiple fates which result in adverse effects on living beings [6]. Hence, to clean up the contaminated soil and water, several technologies such as soil washing, vitrification and solidification have been practiced since years [8]. All these technologies are efficient, but consume a lot of energy and economy in the clean-up process [62]. Phytoremediation is one of the technologies which exploit plants to remediate the contaminated medium such as soil, water and air. It greatly contributes to eco-restoration of contaminated sites polluted with heavy metals, organic compounds as well as some of the radionuclides (Chen et al. [13]; Mahar et al. [34]). It is gaining much importance due to its economic feasibility [14]. Certain plants have the innate detoxifying mechanism to convert organic compounds to innocuous state, while the species of Brassicaceae family tend to volatilize organic form of $\mathrm{Hg}$ to inorganic form, liberating it further into the atmosphere [2]. Plants like Helianthus annuus extract high amount of Al; Brassica juncea extracts $\mathrm{Zn}$ and $\mathrm{Ni}$, while Paspalum vaginatum extracted $\mathrm{Cd}, \mathrm{Cu}$ and $\mathrm{Zn}$ into its aboveground biomass $[18,61]$. Every plant has its own innate capacity of thriving in the contaminated medium and remediating it which depends on its individual pollution tolerance mechanism [53]. Phytoremediation studies conducted till date have identified more than 400 species as hyperaccumulators $[1,55]$, but most of them are edible ones which pose a trivial question of trespassing several levels of the food chain, while some efficient ornamental species identified for the purpose have lower biomass, making it unfavorable for phytoremediation [27, 51]. Most of the literature available has recorded edible plants with their successful traits in extracting heavy metals $[12,28]$. It is the need of the current hour to explore other species such as weeds popularly termed as unwanted plants. Weedy plants are highly suitable for the purpose of phytoremediation as they are naturally resistant to pollution and due to their unsuitability as fodder [21].

Venkatachalam et al. [59] studied Acalypha indica to be $\mathrm{a} \mathrm{Pb}$ accumulator with a defense mechanism to detoxify the $\mathrm{Pb}$-induced toxic effect on it, whereas a very high accumulation of $\mathrm{Cd}, \mathrm{Cu}$ and $\mathrm{Zn}$ was noted in Amaranthus viridis growing locally over heavily polluted soils [9]. Also, the literature shows the accumulating potential of species targeted for $\mathrm{Cr}, \mathrm{Cu}, \mathrm{Ni}, \mathrm{Cd}, \mathrm{Pb}$ and $\mathrm{Zn}$ as reported by [15]. The maximum accumulation of $\mathrm{Cr}(\mathrm{VI})$ was recorded in $A$. viridis growing close to the soil polluted with waste discarded by chromium producing factory [68]. Ameh et al. [3] through the study showed $A$. viridis to be a phytostabilizer of $\mathrm{Zn}$ and Mo when grown over heavy metal-polluted soil.

Hence, based on good accumulatory trends as per the available literature, two weed species Acalypha indica and Amaranthus viridis were selected for the present study. The study aimed at checking the accumulating efficiencies of the heavy metals from effluent contaminated soil as well as to access its translocation potential from the underground to the aboveground biomass, thereby comparing its efficiencies to other species. The main objective behind selecting these two plant species was based on the preliminary screening conducted well before the present study was designed. During preliminary study, a total of four species were checked for the heavy metal concentration in their aboveground biomass growing over the contaminated sites. The plants present there included Amaranthus spinosus, Acalypha indica, Amaranthus viridis, Calotropis procera, Cassia tora and Cynodon dactylon. Out of which only the first four species were selected and subjected to heavy metal analysis, while Cynodon dactylon and Calotropis procera were omitted as the former is a grass variety with less biomass and the latter due to it invasiveness is toxic milk producing fruits. Based on the highest $\mathrm{BCF}$ and TF values obtained for $\mathrm{Pb}, \mathrm{Zn}, \mathrm{Cr}$ and $\mathrm{Cu}$ in this two species compared to the others, they were selected for further ex situ studies.

The present study focuses on the potential of the species to thrive over soil externally spiked with two doses of paint industry effluent and to check the exact mechanism of phytoremediation and the exact localization of different heavy metals present in the effluent spiked soil finally evaluating its BCF and TF factors. The hypothesis of the present work states the positive correlation of heavy metals in the biomass of the species exposed to different treatments of paint industry effluent.

\section{Methodology}

\subsection{Characterization of the experimental soil}

\subsubsection{Collection of composite soil sample}

The Botanical Garden of Natubhai V. Patel College of Pure and Applied Sciences was selected to set up the experiment for the present study. Hence, several random soil samples from 10 to $15 \mathrm{~cm}$ depth were collected from the garden and mixed thoroughly to make a composite sample for the physicochemical characterization. This soil was air-dried for 2 weeks and sieved with a 2-mm mesh and then preserved in polyethylene bag for further chemical analysis of soil. 


\subsubsection{Physicochemical analysis}

The physical parameter analysis such as texture analysis was carried out using Jar Method; the bulk density, pore space and moisture content were also checked [35]. The $\mathrm{pH}$ was determined by suspending $20 \mathrm{~g}$ of soil in 100$\mathrm{ml}$ double-distilled water (1:2.5) ratio, and then, it was homogenized on the mechanical shaker for about an hour after which the $\mathrm{pH}$ was checked using a $\mathrm{pH}$ meter. The organic carbon and organic matter were determined using Walkley and Black [60] method. The $\mathrm{Na}$ and K content from the soil was extracted in sodium acetate solution which was determined by flame photometer using sodium chloride and potassium chloride salt solutions for preparing the standard curve. The total nitrogen was estimated by Kjeldahl method, and available phosphorous was checked using Olsen's method.

\subsubsection{Acid digestion for heavy metal analysis}

The soil sample was acid digested on a hot plate; $1 \mathrm{~g}$ of soil was taken in a borosilicate measuring cylinder after which $7.5 \mathrm{ml}$ concentrated nitric acid, $2.5 \mathrm{ml}$ of concentrated hydrochloric acid and $1 \mathrm{ml}$ of hydrogen peroxide were added to it and was further boiled till its volume halved. After cooling, it was filtered with Whatman filter paper No. 1 and the final volume was made up to $25 \mathrm{ml}$ with double-distilled water [47]. Heavy metals ( $\mathrm{Pb}, \mathrm{Zn}, \mathrm{Cr}$ and $\mathrm{Cu}$ ) were than determined by inductive coupled plasma optical emission spectroscopy (ICP-OES) using a PerkinElmer Model Optima 3300 RL spectrometer at Sophisticated Instrumentation Centre for Applied Research \& Testing (SICART), Anand, India.

\subsection{Effluent collection and characterization}

\subsubsection{Effluent collection site}

The effluent was collected from a paint industry effluent outlet located in Vitthal Udyognagar $\left(22.54716^{\circ} \mathrm{N}\right.$ $\left.72.91414^{\circ} \mathrm{E}\right)$, a town in the Anand District of Gujarat with multitude of industries. The effluent was collected in a 20-L carboy and was brought to the laboratory to carry out the phytoremediation study.

\subsubsection{Physicochemical characterization}

The dissolved oxygen was immediately fixed at the point of collection and was further analyzed using Winkler method in laboratory [38]. The sample was used for other physicochemical analysis too such as turbidity using nephelometric method, $\mathrm{pH}$ using a digital $\mathrm{pH}$ meter calibrated using buffer tables of 4 and $9 \mathrm{pH}$ range, electrical conductivity using conductivity meter calibrated using standard potassium chloride solution, biochemical oxygen demand using direct method, chemical oxygen demand by dichromate reflux method [37], sulfate using turbidimetric method, and phosphate was analyzed using stannous chloride method, sodium and potassium using flame photometric method, chloride by Mohr method [30], nitrate by phenoldisulfonic acid method, hardness (calcium and magnesium) by titrimetric method and the total solids using Whatman filter paper. All these parameters were analyzed within 7 days from the day of sampling, and the analysis was carried out using Handbook of water and wastewater analysis [35], while the heavy metal analysis of the effluent was carried out using ICP-OES at SICART.

\subsection{Experimental setup}

\subsubsection{Preparation of soil bed to grow experimental species}

An appropriate place receiving moderate sunlight and proper water supply was selected in the garden. Six experimental plots of $1.5 \mathrm{~m} \times 1.2 \mathrm{~m}$ size were designed using bricks. A total of two plots were designed for species grown under controlled condition, one for Acalypha indica and the other for Amaranthus viridis, and the other four plots were prepared with two for each species grown under two effluent treatments, i.e., 50\% and 100\% (Fig. 1).

\subsubsection{Spiking of the soil with the effluent treatments}

The plants species were exposed to $50 \%$ and $100 \%$ paint industry effluent treatments. The $50 \%$ dose was prepared by diluting one-half of the effluent with distilled water. After that, two plots were spiked with $5 \mathrm{~L}$ of $50 \%$ dose, while the other two were spiked with $5 \mathrm{~L}$ of $100 \%$ dose for Acalypha indica as well as for Amaranthus viridis, respectively. Composite soil samples were collected from all the four individual plots containing doses as well as from both the control plots for the initial heavy metal analysis before transplanting the experimental species. Now, the plant saplings of both the species were grown over the spiked soil in 3 rows and 5 columns such that the distance between saplings in column was 15 inches, while that in row was 10 inches. The experiment was carried out for a period of 45 days with water sprinkled ever third day on the species till the end of the experiment.

\subsubsection{Sampling and analysis of plant biomass and the soil}

All the treated plants were uprooted carefully, and their respective soil samples were collected too, followed by proper washing of plants, and finally, they were separated into root and shoot parts. Further, they were sun-dried for 


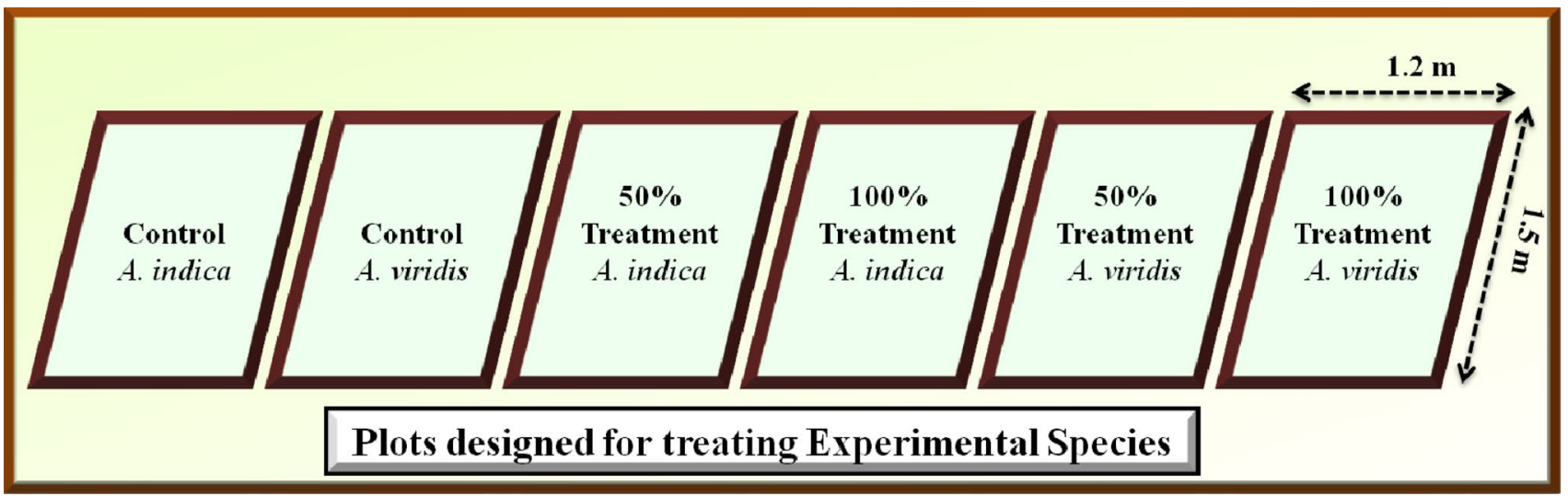

Fig. 1 Schematic diagram of the designed plots for the experimental study

a period of a week and crushed using mortar and pestle. One gram of each dried sample was acid digested and given for ICP-OES analysis at SICART.

\section{Evaluating the remedial quotient of the plant species}

\subsection{Bioconcentration factor (BCF)}

Bioconcentration factor accounts for the total amount of heavy metal accumulated in the plant from the contaminated medium. It also gives an insight into the capability of plant to serve the purpose of phytoextraction or phytostabilization [31, 33].

$[\text { Heavy Metal }]_{\text {Plant Biomass }} /[\text { Heavy Metal }]_{\text {Soil }}$

\subsection{Translocation factor (TF)}

The translocation factor states the potential of the species under study to transfer the element absorbed in the root zone to further transport it to the aboveground biomass $[11,52]$.

$[\text { Heavy Metal }]_{\text {Root }} /[\text { Heavy Metal }]_{\text {Shoot }}$

\subsection{Statistical analysis}

The data were analyzed using PAST version 3.24, and the treatment means were analyzed separately using Dunn's test after it was determined that there was significant difference $(P<0.05)$ on the accumulation efficiencies pertaining to the application of several doses using one-way analysis of variance.

\section{Results}

The experimental soil was slightly acidic with moderate organic carbon and organic matter as given in Table 1 .

The paint industry effluent (PIE) had an acidic $\mathrm{pH}$ of 5.7 and EC $567 \mu \mathrm{S} / \mathrm{cm}$, the BOD measured was $358 \mathrm{mg} / \mathrm{l}$, while the COD content was $743 \mathrm{mg} / \mathrm{l}$, the TDS and TSS of the effluent were 1195 and 1200, and the sodium and potassium were $155 \mathrm{mg} / \mathrm{l}$ and $8 \mathrm{mg} / \mathrm{l}$, respectively, the DO was $1.89 \mathrm{mg} / \mathrm{l}$, and the turbidity measured was $42 \mathrm{NTU}$, while the phosphate, sulfate and nitrate were detected to be $4.33 \mathrm{mg} / \mathrm{l}, 30.8 \mathrm{mg} / \mathrm{l}$ and $15 \mathrm{mg} / \mathrm{l}$, respectively, and the hardness of calcium and the magnesium was $147 \mathrm{mg} / \mathrm{l}$ and $181 \mathrm{mg} / \mathrm{l}$ (Table 2). The heavy metal composition of paint industry effluent is given in Table 3.

Table 1 Physicochemical characterization of the experimental soil

\begin{tabular}{lll}
\hline Parameters & Unit & Value \\
\hline Physical parameters & $\%$ & \\
Sand & $\%$ & 66.66 \\
Silt & $\%$ & 11.90 \\
Clay & $\mathrm{gm} / \mathrm{cm}^{3}$ & 21.44 \\
Bulk density & $\%$ & 1.34 \\
Moisture content & $\%$ & 3.80 \\
Pore space & & 49.433 \\
Chemical parameters & - & \\
pH & $\mu \mathrm{s} / \mathrm{m}$ & 6.7 \\
EC & $\%$ & 589 \\
Organic carbon & $\%$ & 1.2 \\
Organic matter & $\mathrm{mg} / \mathrm{kg}$ & 2.07 \\
Sodium & $\mathrm{mg} / \mathrm{kg}$ & 60 \\
Potassium & $\mathrm{mg} / \mathrm{kg}$ & 140 \\
Available phosphorous & $\%$ & 9.86 \\
Total nitrogen & & 0.13 \\
\hline
\end{tabular}


Table 2 Heavy metal composition of the experimental soil

\begin{tabular}{lll}
\hline Heavy metals & Unit & Value \\
\hline Lead & $\mathrm{mg} / \mathrm{kg}$ & $\mathrm{ND}$ \\
Zinc & $\mathrm{mg} / \mathrm{kg}$ & 3.02 \\
Chromium & $\mathrm{mg} / \mathrm{kg}$ & 0.92 \\
Copper & $\mathrm{mg} / \mathrm{kg}$ & 1.26 \\
\hline
\end{tabular}

$N D$ not detected

Table 3 Heavy metal composition of the paint industry effluent

\begin{tabular}{lll}
\hline Heavy metals & $\begin{array}{l}\text { Concentration } \\
\text { obtained in PIE in } \\
(\mathrm{mg} / \mathrm{l})\end{array}$ & $\begin{array}{l}\text { Effluent discharge } \\
\text { standards maximum } \\
\text { limit } \\
\mathrm{BIS}(2012) \mathrm{in}(\mathrm{mg} / \mathrm{l})\end{array}$ \\
\hline $\mathrm{Pb}$ & 12.48 & 2.0 \\
$\mathrm{Zn}$ & 18.36 & 5.0 \\
$\mathrm{Cr}$ & 9.54 & 2.0 \\
$\mathrm{Cu}$ & 5.67 & 3.0 \\
\hline
\end{tabular}

\subsection{Heavy metal distribution over the root and shoot regions}

Acalypha indica showed a moderate $9.5 \mathrm{mg} / \mathrm{kg}$ of $\mathrm{Pb}$ accumulation in the root zone transferring $0.73 \mathrm{mg} / \mathrm{kg}$ to the shoot spiked with $50 \%$ effluent with an overall accumulation of $32.78 \%$ in its overall biomass (root + shoot) leaving $18.76 \mathrm{mg} / \mathrm{kg}$ in soil and $28.32 \mathrm{mg} / \mathrm{kg}$ root accumulation transferring 11.54 further to the shoot zone in $100 \%$ effluent treatment accumulating a total of $63.87 \%$ leaving $19.8 \mathrm{mg} / \mathrm{kg}$ residual $\mathrm{Pb}$ portion in the soil.

Similarly, A. viridis also accumulated $14.53 \mathrm{mg} / \mathrm{kg}$ and $7.3 \mathrm{mg} / \mathrm{kg} \mathrm{Pb}$ in the root and the shoot zones leaving $6.9 \mathrm{mg} / \mathrm{kg}$ in soil with an overall sequestration of $69.96 \%$ pertaining to $50 \%$ treatment and $28.47 \mathrm{mg} / \mathrm{kg}$ and $18.13 \mathrm{mg} / \mathrm{kg}$ with total accumulation of $74.67 \%$ in $100 \%$ treatment leaving $11.5 \mathrm{mg} / \mathrm{kg}$ residual in soil, and it was significantly different at $(P<0.05)$ (Figs. 2,3$)$.

Acalypha indica accumulated $5.14 \mathrm{mg} / \mathrm{kg}$ of $\mathrm{Zn}$ in the root zone and $15.33 \mathrm{mg} / \mathrm{kg}$ in the shoot zone leading to an overall $44.58 \% \mathrm{Zn}$ accumulation in $50 \%$ treatment leaving $20.13 \mathrm{mg} / \mathrm{kg}$ residual $\mathrm{Zn}$ in the soil. In 100\% treatment, it accumulated $58.52 \mathrm{mg} / \mathrm{kg}$ in the root zone, while in the shoot, it accumulated $10.39 \mathrm{mg} / \mathrm{kg}$ with an overall $75.06 \%$ $\mathrm{Zn}$ accumulation leaving $22.2 \mathrm{mg} / \mathrm{kg}$ residual in the soil. The $\mathrm{Zn}$ accumulation across several parts of species was significant at $(P<0.05)$.

Similarly, A. viridis accumulated $2.81 \mathrm{mg} / \mathrm{kg}$ and $15.83 \mathrm{mg} / \mathrm{kg}$ in the root and shoot regions, respectively, exposed to $50 \%$ treatment with an overall accumulation of $40.61 \%$ leaving $21.9 \mathrm{mg} / \mathrm{kg}$ residual portion of $\mathrm{Zn}$ in soil and $27.08 \mathrm{mg} / \mathrm{kg}$ and $41.08 \mathrm{mg} / \mathrm{kg}$ in root and shoot exposed to $100 \%$ treatment with overall $74.24 \%$

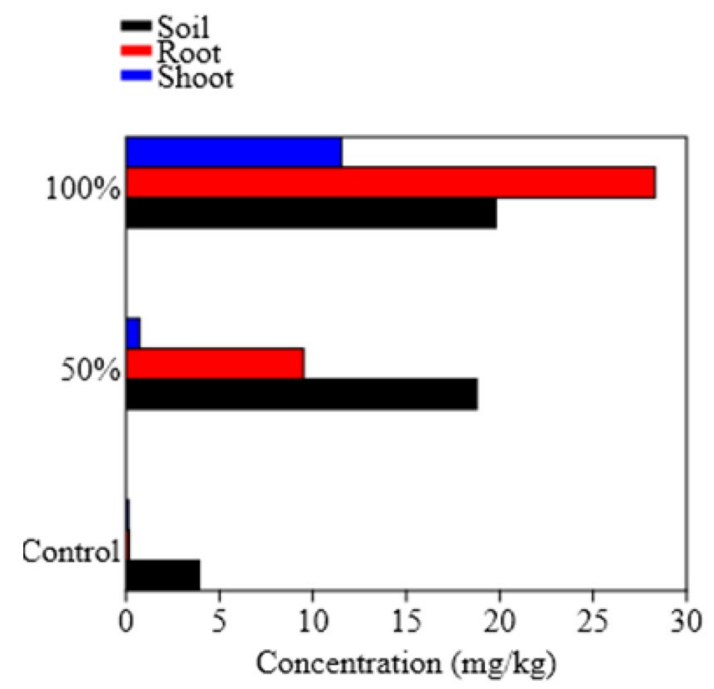

Fig. 2 Accumulation of lead in root and shoot region of Acalypha indica

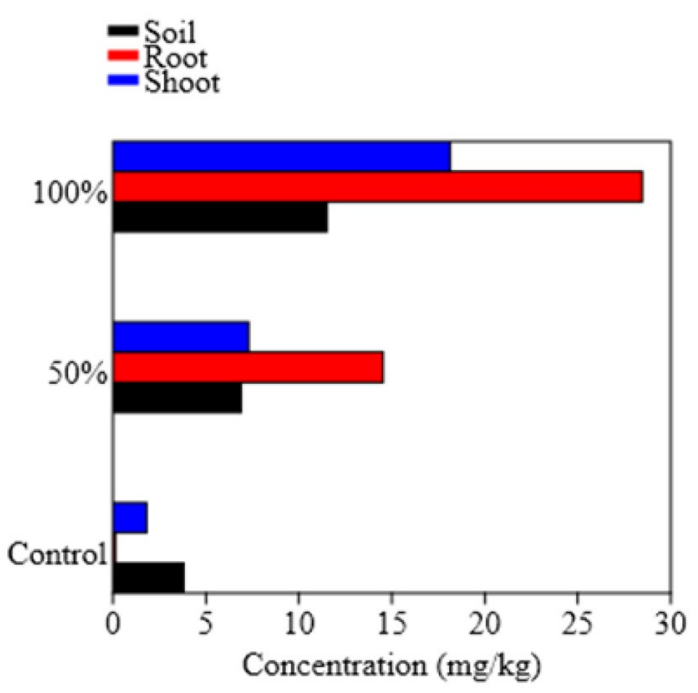

Fig. 3 Accumulation of lead in root and shoot region of Amaranthus viridis

accumulation leaving $21.4 \mathrm{mg} / \mathrm{kg}$ as residual portion in soil (Figs. 4, 5).

The present study revealed that $A$. indica sequestered $6.26 \mathrm{mg} / \mathrm{kg}$ of $\mathrm{Cr}$ in the root part transferring $10.91 \mathrm{mg} /$ $\mathrm{kg}$ to the shoot leaving $5.9 \mathrm{mg} / \mathrm{kg}$ in soil in $50 \%$ effluent treatment with an overall chromium accumulation of $71.99 \%$ in its biomass and $15.89 \mathrm{mg} / \mathrm{kg}$ root accumulation and further transferring $20.78 \mathrm{mg} / \mathrm{kg}$ to the shoot zone in $100 \%$ effluent treatment accumulating total of $76.87 \%$ leaving $8.96 \mathrm{mg} / \mathrm{kg}$ residual $\mathrm{Cr}$ portion in the soil, and the values obtained were significantly different for different treatments $(P<0.05)$. 


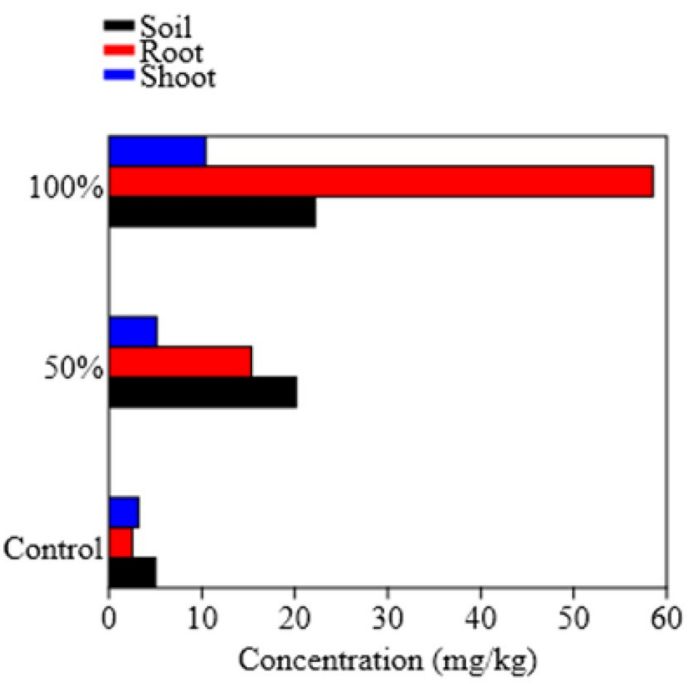

Fig. 4 Accumulation of zinc in root and shoot region of Acalypha indica

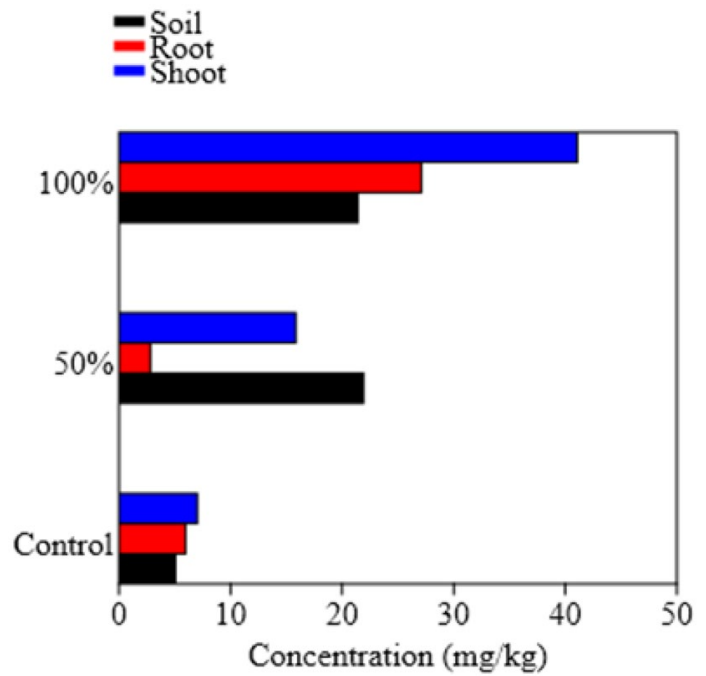

Fig. 5 Accumulation of zinc in root and shoot region of Amaranthus viridis

Similarly, A. viridis also accumulated $5.54 \mathrm{mg} / \mathrm{kg}$ and $12.0 \mathrm{mg} / \mathrm{kg} \mathrm{Cr}$ in the root and the shoot zones, respectively, leaving $4.56 \mathrm{mg} / \mathrm{kg}$ in soil with an overall sequestration of $73.75 \%$ pertaining to $50 \%$ treatment and $17.84 \mathrm{mg} /$ $\mathrm{kg}$ and $21.45 \mathrm{mg} / \mathrm{kg}$ leaving $7.32 \mathrm{mg} / \mathrm{kg}$ in soil with total accumulation of $82.36 \%$ in $100 \%$ treatment which was significant $(P<0.05)$ (Figs. 6, 7).

Acalypha indica accumulated $7.94 \mathrm{mg} / \mathrm{kg}$ of $\mathrm{Cu}$ in the root translocating $3.99 \mathrm{mg} / \mathrm{kg}$ to the shoot region leaving $5.56 \mathrm{mg} / \mathrm{kg}$ in soil in $50 \%$ effluent treatment with an overall accumulation of $84.19 \%$ in its biomass and $15.54 \mathrm{mg} / \mathrm{kg}$ root accumulation transferring $4.98 \mathrm{mg} / \mathrm{kg}$ further to the shoot zone in $100 \%$ effluent treatment accumulating total

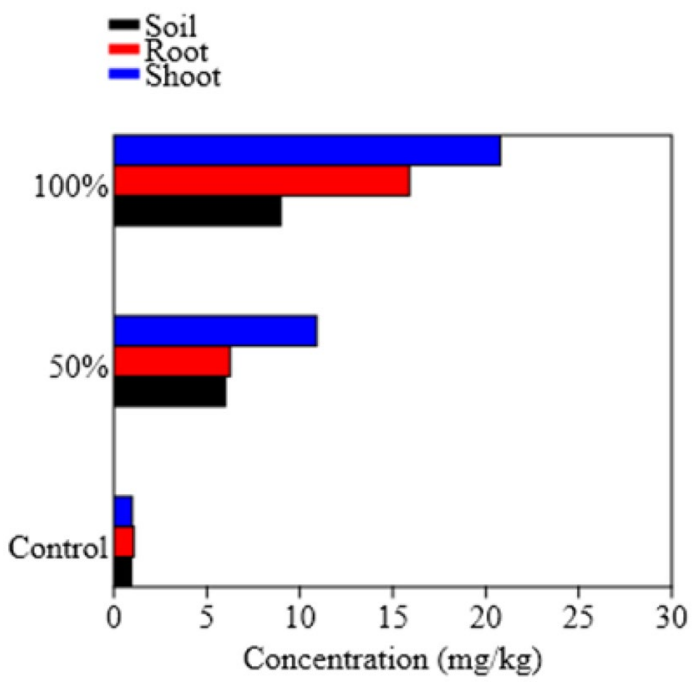

Fig. 6 Accumulation of chromium in root and shoot region of Acalypha indica

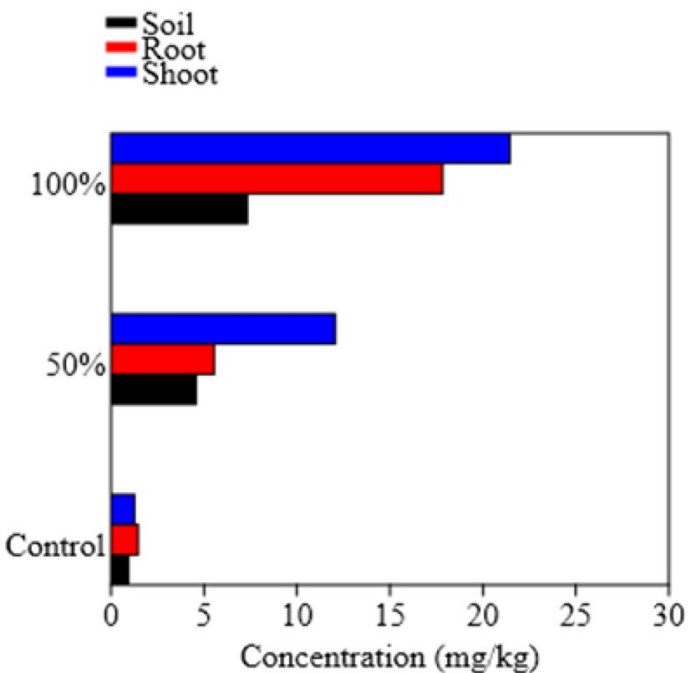

Fig. 7 Accumulation of chromium in root and shoot region of Amaranthus viridis

of $66.46 \%$ leaving the $8.32 \mathrm{mg} / \mathrm{kg}$ residual Cu portion in the soil, and it was not significantly different at $(P<0.05)$.

Similarly, A. viridis also accumulated $7.91 \mathrm{mg} / \mathrm{kg}$ and $1.67 \mathrm{mg} / \mathrm{kg}$ of $\mathrm{Cu}$ in the root and the shoot zones with $6.21 \mathrm{mg} / \mathrm{kg}$ residual in the soil with an overall sequestration of $67.6 \%$ pertaining to $50 \%$ treatment and $17.25 \mathrm{mg} /$ $\mathrm{kg}$ in root and $2.98 \mathrm{mg} / \mathrm{kg}$ in shoot with total accumulation of $71.35 \%$ in $100 \%$ treatment leaving $7.32 \mathrm{mg} / \mathrm{kg}$ residual $\mathrm{Cu}$ in soil which was not significant at $(P<0.05)$ (Figs. 8, 9).

The BCF value obtained in case of $A$. indica for $100 \%$ treatment was $\mathrm{Cr}(4.09)>\mathrm{Zn}(3.1)>\mathrm{Cu}(2.46)>\mathrm{Pb}$ (2.01), and a similar trend in $50 \%$ treatment was seen, i.e., $\mathrm{Cr}$ (2.09) $>\mathrm{Zn} \mathrm{(1.01)>Cu} \mathrm{(2.09)}>\mathrm{Pb}$ (0.54), and in $100 \%$

\section{SN Applied Sciences}




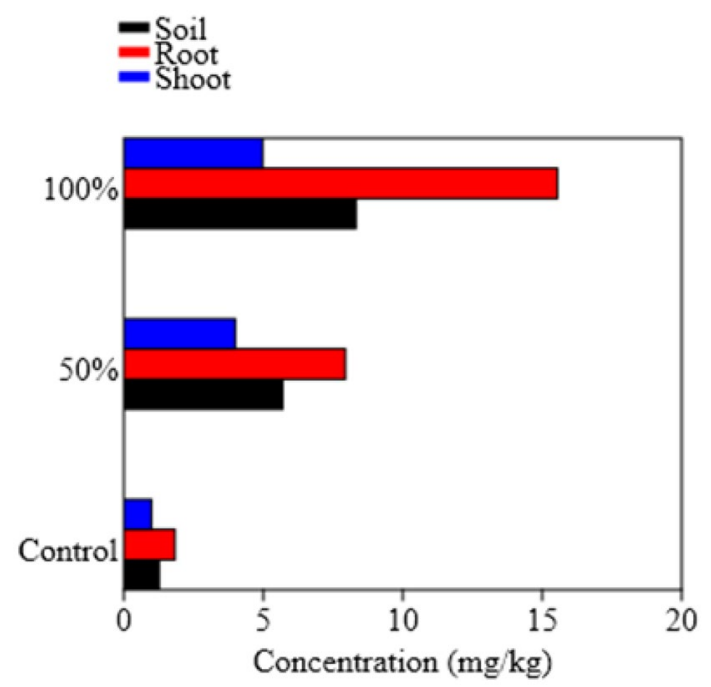

Fig. 8 Accumulation of copper in root and shoot region of Acalypha indica

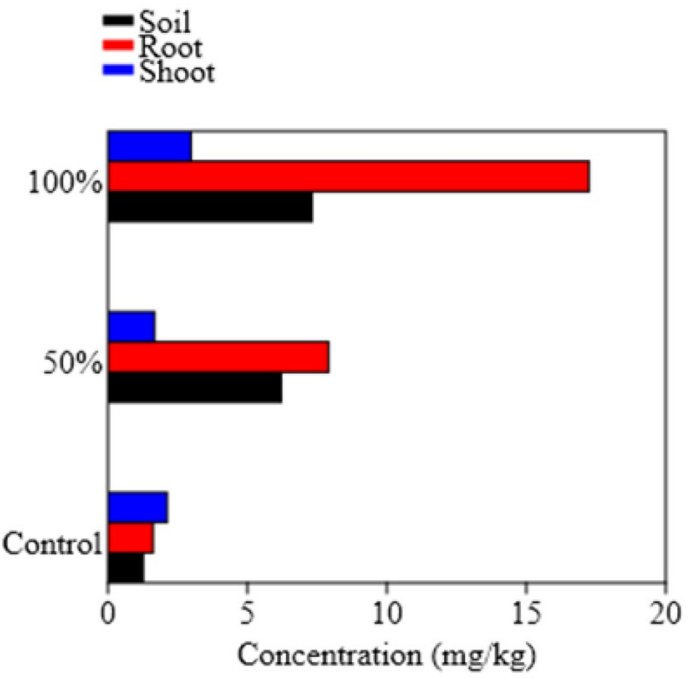

Fig. 9 Accumulation of copper in root and shoot region of Amaranthus viridis

treatment of $A$. viridis, it was $\mathrm{Cr}(5.36)>\mathrm{Pb}(4.05)>\mathrm{Zn}$ (3.1) $>\mathrm{Cu}(0.17)$, while in $50 \%$ treatment, it was $\mathrm{Cr}$ (3.85) $>\mathrm{Pb}(3.16)>\mathrm{Cu}(1.54)>\mathrm{Zn}(0.85)$.

The TF in case of Acalypha indica was $>1$ only for $\mathrm{Cr}$, while it was $<1$ for $\mathrm{Pb}, \mathrm{Zn}$ and $\mathrm{Cu}$, whereas in case of Amaranthus viridis, it was $>1$ for $\mathrm{Zn}$ and $\mathrm{Cr}$ and $<1$ for $\mathrm{Pb}$ and $\mathrm{Cu}$.

Here, as per the data, it was observed that Acalypha indica showed high bioaccumulation of all the heavy metals except $50 \% \mathrm{~Pb}$ treatment and the values were also significantly different at $(P<0.05)$ for all the heavy metals. Similarly, Amaranthus viridis showed high bioaccumulation of all the heavy metals and the exception being $50 \% \mathrm{Zn}$ was noted and also the data were significant at $(P<0.05)$.

\section{Discussion}

Gunwal et al. [22] stated Pb to be a heavy metal having less solubility and so usually even at elevated levels, it shows restricted mobility and if it gets accumulated in the root, it transfers very less amount to other aerial parts of most of the plants. Ancona et al. [7] in their classification of heavy metals showed $\mathrm{Pb}$ and $\mathrm{Cr}$ to be the least bioavailable among all. This report justifies with the current findings where at elevated levels of $\mathrm{Pb}$ in the soil, the uptake in the shoot of $A$. indica increased in $100 \%$ treatment, i.e., $63.87 \%$ $\mathrm{Pb}$ accumulation in the total biomass compared to $32.78 \%$ accumulation in 50\% treatment. El-Mahrouk et al. [19] findings supported this trend as he reported that higher TF values in plant species are observed when high metal concentration is present in the soil, making it available to the root region thereby successively translocating a good amount to the shoot part. Plants having $>1 \mathrm{TF}$ are good at phytoextraction [24]. Fritioff and Greger [20] stated the mechanism and utility of plant sequestering highest amount in the root region which is termed as phytostabilization wherein the plant arrests the contaminants near the substrate, further preventing it from spreading or leaching into the ground or to other mediums. Here, for both the treatments, a higher accumulation in the root region was observed with a TF of $<1$ for both the treatments and for both the species which shows the plants to be good at phytostabilizing $\mathrm{Pb}$ rather than phytoextracting it. In a study conducted by ur Rehman et al. [57], A. indica naturally growing in the ambience of industrialized area was collected and analyzed with $\mathrm{Pb}$ concentration noted to be $2.5 \mathrm{mg} / \mathrm{kg}$ and $2.9 \mathrm{mg} / \mathrm{kg}$ in the shoot and root region, respectively, with a $0.9 \mathrm{TF}$ value. The translocation from the root to shoot is also depended on the type of metal ion being phytoextracted, and the affinity of the plant species towered it [48]. Since the advent of phytoremediation took place, many more weedy species were discovered which played an immense role in accumulating good amount of heavy metals despite unfavorable climatic conditions and improper growth medium $[16,44]$. Similar to the current study, the level of $\mathrm{Pb}$ recorded for $A$. viridis was 1.7 and $1.9 \mathrm{mg} / \mathrm{kg}$ in the shoot and root, respectively [57]. Iya et al. [25] showed an accumulation trend using A. wilkesiana where it was seen that the plant had good BCF value but poor TF value which corroborated well with the values obtained during the present study. Ziarati and Alaedini $[66]$ checked the $\% \mathrm{~Pb}$ accumulation during three successive harvests and recorded it to be $32.1 \%, 33.6 \%$ and $35.1 \%$ and stated that the young saplings of Amaranth sps were 


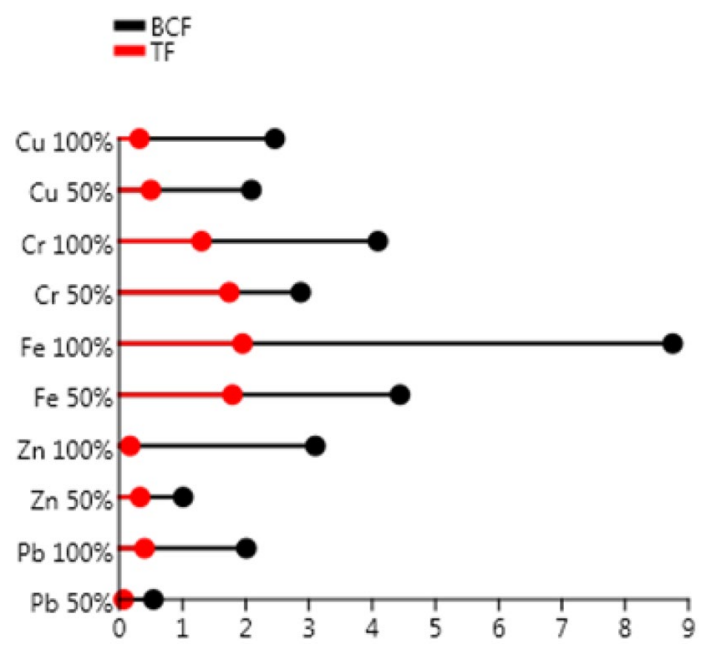

Fig. 10 Bioconcentration and translocation factor of Acalypha indica

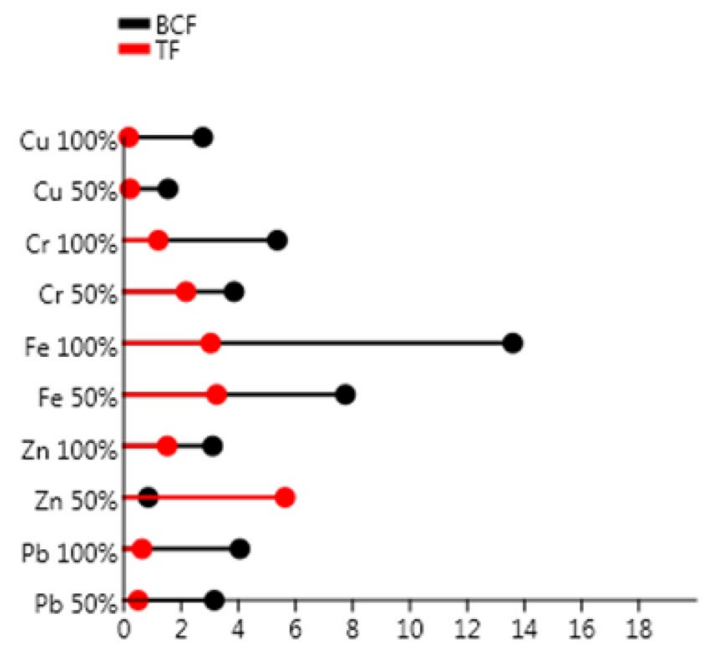

Fig. 11 Bioconcentration and translocation factor of Amaranthus viridis

the most potent in sequestering $\mathrm{Pb}$. Hence, from the data, it can be said that though both the plants have low TF values, yet on comparing both the species it can be stated that $A$. viridis is a good translocator of $\mathrm{Pb}$ compared to $A$. indica from (Figs. 10, 11).

Zinc is an essential element required by plants as well as humans to carry out several metabolic activities as well as enzymatic activities; hence, it is needed in appropriate proportion, but when the concentrations exceed the normal required range, it can cause ill effects leading to malfunctioning and unwanted accumulation in different zones of the body [10]. On analyzing the BCF and TF values, it can be concluded that $A$. indica showed high accumulation of $\mathrm{Zn}$ in the root zone with a translocation factor of $<1$ and a BCF $>1$ for both the treatments of $Z n$ showing phytostabilization of $\mathrm{Zn}$ and less phytoextraction in the aboveground biomass, whereas in $A$. viridis, it not only showed $>1 \mathrm{BCF}$ value but also had $>1 \mathrm{TF}$ value in $100 \%$ treatment, making it a good candidate for phytoextraction of $\mathrm{Zn}$ at elevated concentrations. It can be seen that despite higher concentration of $\mathrm{Zn}$ in the soil, both the plant species extracted good amount in its biomass showing high tolerance toward Zn. Liu et al. [32] stated that though some plants accumulate good amount of heavy metals from the contaminated soil, yet only few species translocate it to the stem as well as leaves, while the rest of the portion remains localized in the root region of the plant owing to the self-defense mechanism of plant.

Several studies have reported chromium to be an essential nutrient for growth of plants at low levels, but at elevated levels, it also poses to have carcinogenic effect [50]. Recently, the concentration of chromium in the environment has been increasing due to its wide range of applications in many industries with paint and pigment being an important area of its use [54]. As per the results obtained, it was observed that the values of BCF exceeded 1 in case of both the species and for both the treatments for $\mathrm{Cr}$, even the TF values for both of them were more than 1 which were contradictory to that of [49].

Reeves and Baker [46] stated that for a species to be a Cu hyperaccumulator, it has to accumulate a total of $1000 \mathrm{mg} / \mathrm{kg}$ of heavy metal in its aboveground biomass. In the present study, $A$. indica accumulated $7.94 \mathrm{mg} / \mathrm{kg}$ of $\mathrm{Cu}$ in the root translocating $3.99 \mathrm{mg} / \mathrm{kg}$ to the shoot region in $50 \%$ effluent treatment and $15.54 \mathrm{mg} / \mathrm{kg}$ root accumulation transferring $4.98 \mathrm{mg} / \mathrm{kg}$ further to the shoot zone in $100 \%$ effluent treatment which corroborated well with the findings by lya et al. [25], where in A. wilkesiana the highest accumulation of $101.23 \pm 2.92 \mathrm{mg} / \mathrm{kg}$ was found in the root region, while that in the stem accounted to $76.93 \pm 1.27$ and in the leaf region was $79.39 \pm 2.57 \mathrm{mg} / \mathrm{kg}$. Generally, the plant species have been observed to have very less potential in phytoextracting $\mathrm{Cu}$ from the soil compared to other heavy metals [56]. Also, the accumulation of multimetal contaminated soil depends on different factors such as soil $\mathrm{pH}$, soil organic matter, its affinity with other metals present as well as the plant species and the texture of the soil [29]. The accumulation of $\mathrm{Cu}$ in the aerial parts of the plants is solely dependent on the concentration of the metal present in the soil, and its uptake increases at elevated levels of $\mathrm{Cu}$ in the soil $[58,63]$. The results thus obtained exhibited a pattern similar to the one obtained by [65]. In a study, a gradual increase in the \% Cu uptake was recorded to be $10.76,12.46$ and 13.09 during three consecutive harvests in Amaranth sps. during the 45 day study with the maximum uptake rate recorded on the 30th day [66]. The overall BCF for Cu was higher in case of A. indica for both the effluent treatments but had low TF, and 
A. viridis accumulated very less amount of $\mathrm{Cu}$ supported by low BCF values for both the treatments as well as very low TF values showing that it was an excluder of $\mathrm{Cu}$ as per the observations made from the present study. Zhao and Duo [65] reported in a study that some of the plants act as excluders by not letting the pollutants enter their metabolic pathways to protect themselves as a self-defensive action and inhibiting the concentration to exceed in the root zone by eliminating its entry selectively.

The prime mode of entry of any element is the root cells which are in deep association with the soil to fulfill its nutritional needs, and it thus also makes way for the entry of many more non-essential elements such as heavy metals present anthropogenically in the root via the soil by liberating natural organic chelating agents and increasing the solubility of these heavy metals which finally reaches the foliar zones of the plants [17].

Hence, these default mechanisms observed have been applied to clean the contaminated lands and to seek out such potential plants for the reclamation purpose.

Ndeda and Manohar [40] state that the plant applicable for the purpose of phytoremediation requires high bioconcentration factor (BCF); the higher the $\mathrm{BCF}$, the more the accumulation in the plant tissue compared to its contaminated medium. Similarly, a translocation factor (TF) above 1 shows its transferring mechanism from root to shoot; hence, it makes it a good choice for reclamation and finally an appropriate choice for aboveground harvesting of the heavy metals over wastelands.

As adopted by Pachura et al. [43], a four-scale study to differentiate the levels of heavy metal accumulation among the species was considered and it categorized $>0.01 \mathrm{BCF}$ value as 'no accumulation,' 0.01 to 0.1 as 'low accumulation', 0.1 to 1.0 as 'medium accumulation' and $<1$ to be 'high bioaccumulation.'It was observed that the BCF values increased with the increase in the respective doses of every heavy metal; hence, it can be said that the BCF values are dose as well as species dependent [67]. Hence, as shown in (Figs. 10,11), a high amount of essential heavy metals was accumulated in the shoot tissues of both the experimental species which was also in accordance with other findings of $[4,36]$.

\section{Conclusion}

In the present study, it was observed that both the species Acalypha indica and Amaranthus viridis sequestered good amount of heavy metals in their biomass, making it feasible for growing over contaminated sites for reclamation purpose. In $50 \%$ treatment, $A$. indica accumulated $15.33 \mathrm{mg} / \mathrm{kg}$ of $\mathrm{Zn}$ in the root zone and $5.14 \mathrm{mg} / \mathrm{kg}$ in the shoot zone, whereas in $100 \%$ treatment, it accumulated
$58.52 \mathrm{mg} / \mathrm{kg}$ in the root zone, while $10.39 \mathrm{mg} / \mathrm{kg} \mathrm{Zn}$ in the shoot. A. viridis accumulated $2.81 \mathrm{mg} / \mathrm{kg}$ and $15.83 \mathrm{mg} / \mathrm{kg}$ $\mathrm{Zn}$ in the root and shoot regions, respectively, exposed to $50 \%$ treatment and $27.08 \mathrm{mg} / \mathrm{kg}$ and $41.08 \mathrm{mg} / \mathrm{kg} \mathrm{Zn}$ in root and shoot exposed to $100 \%$ treatment; it also accumulated $5.54 \mathrm{mg} / \mathrm{kg}$ and $12.0 \mathrm{mg} / \mathrm{kg} \mathrm{Cr}$ in the root and the shoot zones, respectively, pertaining to $50 \%$ treatment and $17.84 \mathrm{mg} / \mathrm{kg}$ and $21.45 \mathrm{mg} / \mathrm{kg}$ in $100 \%$ treatment. From the study, it was derived that exploiting plants which are not edible and are pollution tolerant can enhance the rate of phytoremediation and also can stop its transfer across several trophic levels of the food chain.

\section{Compliance with ethical standards}

Conflict of interest On behalf of all authors, the corresponding author states that there is no conflict of interest.

\section{References}

1. Adesodun JK, Atayese MO, Agbaje TA, Osadiaye BA, Mafe OF, Soretire AA (2010) Phytoremediation potentials of sunflowers (Tithonia diversifolia and Helianthus annuus) for metals in soils contaminated with zinc and lead nitrates. Water Air Soil Pollut 207(1-4):195-201

2. Ahmed IG, Sulaiman M, Abdurrahman A, Abdulkarim AD (2018) Phytoremediation: a preeminent alternative method for bioremoval of heavy metals from environment. J Adv Res Appl Sci Eng Technol 10:59-71

3. Ameh EG, Omatola OD, Akinde SB (2019) Phytoremediation of toxic metal polluted soil: screening for new indigenous accumulator and translocator plant species, northern Anambra Basin, Nigeria. Environ Earth Sci 78(12):345

4. Ahmad A, Al-Othman AA (2014) Remediation rates and translocation of heavy metals from contaminated soil through Parthenium hysterophorus. Chem Ecol 30(4):317-327

5. Alloway BJ (2013) Introduction: in heavy metals in soils. Springer, Dordrecht, pp 3-9

6. Åkerblom S, Bååth $\mathrm{E}$, Bringmark L, Bringmark E (2007) Experimentally induced effects of heavy metal on microbial activity and community structure of forest mor layers. Biol Fertil Soils 44(1):79-91

7. Ancona V, Caracciolo AB, Campanale C, Rascio I, Grenni P, Di Lenola M, Bagnuolo G, Uricchio VF (2019) Heavy metal phytoremediation of a poplar clone in a contaminated soil in southern Italy. J Chem Technol Biotechnol. https://doi.org/10.1002/ jctb.6145

8. Ashraf S, Ali Q, Zahir ZA, Ashraf S, Asghar HN (2019) Phytoremediation: environmentally sustainable way for reclamation of heavy metal polluted soils. Ecotoxicol Environ Saf 174:714-727

9. Avkopashvili G, Gongadze A, Gakhokidze R, Avkopashvili M (2015) Phytoremediation of contaminated soils, contaminated with heavy metals from gold mine in Georgia. In: Proceedings of international conference applied ecology: problems, innovations, Tbilisi, Georgia, pp 154-157

10. Bandiera M, Dal Cortivo C, Barion G, Mosca G, Vamerali T (2016) Phytoremediation opportunities with alimurgic species in metal-contaminated environments. Sustainability 8(4):357 
11. Barman SC, Sahu RK, Bhargava SK, Chaterjee C (2000) Distribution of heavy metals in wheat, mustard, and weed grown in field irrigated with industrial effluents. Bull Environ Contam Toxicol 64(4):489-496

12. Boechat CL, Pistóia VC, Gianelo C, de Oliveira Camargo FA (2016) Accumulation and translocation of heavy metal by spontaneous plants growing on multi-metal-contaminated site in the Southeast of Rio Grande do Sul state, Brazil. Environ Sci Pollut Res 23(3):2371-2380

13. Chandra R, Saxena G, Kumar V (2015) Phytoremediation of environmental pollutants: an eco-sustainable green technology to environmental management. In: Chandra R (ed) Advances in biodegradation and bioremediation of industrial waste. CRC Press, Boca Raton, pp 1-30. https://doi.org/10.1201/b18218-2

14. Chen SB, Zhu YG, Hu QH (2005) Soil to plant transfer of $238 \mathrm{U}, 226 \mathrm{Ra}$ and $232 \mathrm{Th}$ on a uranium mining-impacted soil fromsoutheastern China. J Environ Radioact 82(2):223-236

15. Chehregani A, Noori M, Yazdi HL (2009) Phytoremediation of heavy-metal-polluted soils: screening for new accumulator plants in Angouran mine (Iran) and evaluation of removal ability. Ecotoxicol Environ Saf 72(5):1349-1353

16. Chinmayee MD, Mahesh B, Pradesh S, Mini I, Swapna TS (2012) The assessment of phytoremediation potential of invasive weed Amaranthus spinosus L. Appl Biochem Biotechnol 167(6):1550-1559

17. Da Silva $C P$, de Almeida $T E$, Zittel $R$, de Oliveira Stremel $T R$, Domingues CE, Kordiak J, de Campos SX (2016) Translocation of metal ions from soil to tobacco roots and their concentration in the plant parts. Environ Monit Assess 188(12):663

18. Doni S, Macci C, Peruzzi E, lannelli R, Masciandaro G (2015) Heavy metal distribution in a sediment phytoremediation system at pilot scale. Ecol Eng 81:146-157

19. El-Mahrouk ESM, Eisa EAH, Hegazi MA, Abdel-Gayed MES, Dewir YH, El-Mahrouk ME, Naidoo Y (2019) Phytoremediation of cadmium-, copper-, and lead-contaminated soil by Salix mucronata (Synonym Salix safsaf). HortScience 54(7):1249-1257

20. Fritioff $\AA$, Greger $M(2003)$ Aquatic and terrestrial plant species with potential to remove heavy metals from stormwater. Int J Phytorem 5(3):211-224

21. Girdhar M, Sharma NR, Rehman H, Kumar A, Mohan A (2014) Comparative assessment for hyperaccumulatory and phytoremediation capability of three wild weeds. 3 Biotech 4(6):579-589

22. Gunwal I, Singh L, Mago P (2014) Comparison of phytoremediation of cadmium and nickel from contaminated soil by Vetiveria zizanioides L. Int J Sci Res Publ 4(10):1-7

23. Harguinteguy CA, Cirelli AF, Pignata MI (2014) Heavy metal accumulation in leaves of aquatic plant Stuckenia filiformis and its relationship with sediment and water in the Suquía river (Argentina). Microchem J 114:111-118

24. Hesami R, Salimi A, Ghaderian SM (2018) Lead, zinc, and cadmium uptake, accumulation, and phytoremediation by plants growing around Tang-e Douzan lead-zinc mine, Iran. Environ Sci Pollut Res 25(9):8701-8714

25. Iya NID, Assim ZB, Ipor IB, Omolayo AO, Umaru IJ, Jume BH (2018) Accumulation and translocation of heavy metals by acalypha wilkesiana parts in the phytoextraction of contaminated soil. Indones J Chem 18(3):503-513

26. Jeričević A, Ilyin I, Vidič S (2012) Modelling of heavy metals: study of impacts due to climate change. In: National security and human health implications of climate change. Springer, Dordrecht, pp 175-189

27. Jiang B, Xing Y, Zhang B, Cai R, Zhang D, Sun G (2018) Effective phytoremediation of low-level heavy metals by native macrophytes in a vanadium mining area, China. Environ Sci Pollut Res 25:31272-31282. https://doi.org/10.1007/s11356-018-3069-9
28. Karbassi S, Malek M, Shahriari T, Zahed MA (2016) Uptake of metals by plants in urban areas. Int J Environ Sci Technol 13(12):2847-2854

29. Kee JC, Gonzales MJ, Ponce O, Ramírez L, León V, Torres A, Loayza-Muro R (2018) Accumulation of heavy metals in native Andean plants: potential tools for soil phytoremediation in Ancash (Peru). Environ Sci Pollut Res 25(34):33957-33966

30. Korkmaz D (2001) Precipitation titration: "determination of chloride by the Mohr method". Methods 2(4):1-6

31. Kumar N, Bauddh K, Kumar S, Dwivedi N, Singh DP, Barman SC (2013) Accumulation of metals in weed species grown on the soil contaminated with industrial waste and their phytoremediation potential. Ecol Eng 61:491-495

32. Liu H, Wang H, Gao W, Liang H, Gao D (2019) Phytoremediation of three herbaceous plants to remove metals from urban runoff. Bull Environ Contam Toxicol 103(2):336-341

33. Liu J, Xin X, Zhou Q (2017) Phytoremediation of contaminated soils using ornamental plants. Environ Rev 26(1):43-54

34. Mahar A, Wang P, Ali A, Awasthi MK, Lahori AH, Wang Q, Zhang $Z$ (2016) Challenges and opportunities in the phytoremediation of heavy metals contaminated soils: a review. Ecotoxicol Environ Saf 126:111-121

35. Maiti SK (2003) Handbook of methods in environmental studies

36. Memon AR, Schröder P (2009) Implications of metal accumulation mechanisms to phytoremediation. Environ Sci Pollut Res 16(2):162-175

37. Moore WA, Kroner RC, Ruchhoft CC (1949) Dichromate reflux method for determination of oxygen consumed. Anal Chem 21(8):953-957

38. Montgomery H, Thom NS, Cockburn A (1964) Determination of dissolved oxygen by the Winkler method and the solubility of oxygen in pure water and sea water. J Appl Chem 14(7):280-296

39. Nazeer S, Hashmi MZ, Malik RN (2014) Heavy metals distribution, risk assessment and water quality characterization by water quality index of the River Soan, Pakistan. Ecol Indic 43:262-270

40. Ndeda LA, Manohar S (2014) Bio concentration factor and translocation ability of heavy metals within different habitats of hydrophytes in Nairobi Dam, Kenya. J Environ Sci Toxicol Food Technol 8(5):42-45

41. Nriagu JO (1996) A history of global metal pollution. Science 272(5259):223

42. Oribhabor BJ (2016) Impact of human activities on biodiversity in Nigerian aquatic ecosystems. Sci Int 4(1):12-20

43. Pachura P, Ociepa-Kubicka A, Skowron-Grabowska B (2016) Assessment of the availability of heavy metals to plants based on the translocation index and the bioaccumulation factor. Desalin Water Treat 57(3):1469-1477

44. Pan P, Lei M, Qiao P, Zhou G, Wan X, Chen T (2019) Potential of indigenous plant species for phytoremediation of metal (loid)contaminated soil in the Baoshan mining area, China. Environ Sci Pollut Res 26(23):23583-23592

45. Rajendiran S, Dotaniya ML, Coumar MV, Panwar NR, Saha JK (2015) Heavy metal polluted soils in India: status and countermeasures. JNKVV Res J 49(3):320-337

46. Reeves RD, Baker AJM (2000) Metal accumulating plants. In: Raskin I, Ensley BD (eds) Phytoremediation of toxic metals: using plants to clean up the environment. Wiley, New York, pp 193-230

47. Saison C, Schwartz C, Morel JL (2004) Hyperaccumulation of metals by Thlaspi caerulescens as affected by root development and Cd-Zn/Ca-Mg interactions. Int J Phytorem 6(1):49-61

48. Santana BVN, de Araújo TO, Andrade GC, de Freitas-Silva L, Kuki KN, Pereira EG, da Silva LC (2014) Leaf morphoanatomy of species tolerant to excess iron and evaluation of their phytoextraction potential. Environ Sci Pollut Res 21(4):2550-2562 
49. Sybhashini V, Swamy AVVS (2013) Phytoremediation of cadmium and chromium from contaminated soils using Physalis minima Linn. Am Int J Res Form Appl Nat Sci 3(1):13-260

50. Shanker AK, Ravichandran V, Pathmanabhan G (2005) Phytoaccumulation of chromium by some multipurpose-tree seedlings. Agrofor Syst 64(1):83-87

51. Shen ZG, Li XD, Wang CC, Chen HM, Chua H (2002) Lead phytoextraction from contaminated soil with high-biomass plant species. J Environ Qual 31(6):1893-1900

52. Singh R, Singh DP, Kumar N, Bhargava SK, Barman SC (2010) Accumulation and translocation of heavy metals in soil and plants from fly ash contaminated area. J Environ Biol 31(4):421-430

53. Stephenson C, Black CR (2014) One step forward, two steps back: the evolution of phytoremediation into commercial technologies. Biosci Horiz Int J Stud Res. https://doi.org/10.1093/bioho rizons/hzu009

54. Singh HP, Mahajan P, Kaur S, Batish DR, Kohli RK (2013) Chromium toxicity and tolerance in plants. Environ Chem Lett 11(3):229-254

55. Tanhan P, Kruatrachue M, Pokethitiyook P, Chaiyarat R (2007) Uptake and accumulation of cadmium, lead and zinc by Siam weed [Chromolaena odorata (L.) King \& Robinson]. Chemosphere 68(2):323-329

56. Tian S, Jia Y, Ding Y, Wang R, Feng R, Song Z, Zhou L (2014) Elevated atmospheric $\mathrm{CO}_{2}$ enhances copper uptake in crops and pasture species grown in copper-contaminated soils in a microplot study. CLEAN Soil Air Water 42(3):347-354

57. ur Rehman MZ, Rizwan M, Ali S, Ok YS, Ishaque W, Nawaz MF, Akmal F, Waqar M (2017) Remediation of heavy metal contaminated soils by using Solanum nigrum: a review. Ecotoxicol Environ Saf 143:236-248

58. Varun M, D'Souza R, Favas PJ, Pratas J, Paul MS (2015) Utilization and supplementation of phytoextraction potential of some terrestrial plants in metal-contaminated soils. In: Phytoremediation. Springer, Cham, pp 177-200

59. Venkatachalam P, Jayalakshmi N, Geetha N, Sahi SV, Sharma NC, Rene ER, Sarkar SK, Favas PJ (2017) Accumulation efficiency, genotoxicity and antioxidant defense mechanisms in medicinal plant Acalypha indica L. under lead stress. Chemosphere 171:544-553

60. Walkley A, Black IA (1934) An examination of the Degtjareff method for determining soil organic matter, and a proposed modification of the chromic acid titration method. Soil Science 37(1):29-38

61. Willscher S, Mirgorodsky D, Jablonski L, Ollivier D, Merten D, Büchel G, Wittig J, Werner P (2013) Field scale phytoremediation experiments on a heavy metal and uranium contaminated site, and further utilization of the plant residues. Hydrometallurgy 131-132:46-53

62. Xia S, Song Z, Jeyakumar P, Shaheen SM, Rinklebe J, Ok YS, Bolan $\mathrm{N}$, Wang $\mathrm{H}$ (2019) A critical review on bioremediation technologies for $\mathrm{Cr}(\mathrm{VI})$-contaminated soils and wastewater. Crit Rev Environ Sci Technol 49:1027-1078

63. Xiong ZT, Wang H (2005) Copper toxicity and bioaccumulation in Chinese cabbage (Brassica pekinensis Rupr.). Environ Toxicol Int J 20(2):188-194

64. Yoon J, Cao X, Zhou Q, Ma LQ (2006) Accumulation of Pb, Cu, and $\mathrm{Zn}$ in native plants growing on a contaminated Florida site. Sci Total Environ 368(2-3):456-464

65. Zhao S, Duo L (2015) Bioaccumulation of cadium, copper, zinc, and nickel by weed species from municipal solid waste compost. Pol J Environ Stud 24(1):413-417

66. Ziarati P, Alaedini S (2014) The phytoremediation technique for cleaning up contaminated soil by Amaranthus sp. J Environ Anal Toxicol 4(208):0525-2161

67. Zhang Z, Rengel Z, Meney K (2010) Cadmium accumulation and translocation in four emergent wetland species. Water Air Soil Pollut 212(1-4):239-249

68. Zou J, Wang M, Jiang W, Liu D (2006) Chromium accumulation and its effects on other mineral elements in Amaranthus viridis L. Acta Biol Crac Ser Bot 48(1):7-12

Publisher's Note Springer Nature remains neutral with regard to jurisdictional claims in published maps and institutional affiliations. 